\title{
Penerapan Teknik Kejutan Verbal untuk Meningkatkan Self Esteem Siswa
}

\author{
Idriani Idris ${ }^{1}$, Arni Ulan ${ }^{2}$
}

Jurusan Bimbingan dan Konseling, Universitas Negeri Gorontalo, Indonesia ${ }^{1}$ Sekolah Menengah Pertama Negeri 1 Tompobulu, Indonesia ${ }^{2}$

Indiraniidris02@ung.ac.id

\begin{tabular}{l|l|l}
\hline Diterima: April 2020 & Disetujui: April 2020 & Dipublikasi: Mei 2020 \\
\hline
\end{tabular}

\begin{abstract}
Abstrak
Permasalahan Pokok yang dikaji dalam penelitian ini yaitu meningkatkan self esteem siswa dengan Teknik Kejutan Verbal. Tujuan penelitian ini (1) Mengetahui gambaran penerapan teknik kejutan verbal,(2) Mengetahui tingkat self esteem siswa sebelum dan sesudah diberikan teknik kejutan verbal, (3) Mengetahui pengaruh teknik kejutan verbal dalam meningkatkan self esteem siswa. Pendekatan penelitian yang digunakan adalah kuantitatif dengan desain pre-experimental, one group pretest-posttest design. Populasi dan sampel penelitian ini adalah siswa kelas X SMA Negeri 9 Makassar yang teridentifikasi memiliki self esteem rendah dengan jumlah sampel penelitian sebanyak 9 orang. Instrumen yang digunakan adalah skala dan observasi. Analisis data yang digunakan adalah analisis deskriptif, dan analisis statistik inferensial dengan $t$-test. Hasil penelitian menunjukkan bahwa: (1) Pelaksanaan teknik kejutan verbal melalui konseling kelompok terdiri dari lima tahap yaitu membangun lingkungan konseling, eksplorasi wants and needs, eksplorasi doing and direction, evaluasi diri serta rencana dan tindakan dimana siswa penuh antusias pada setiap tahap yang dilaksanakan, (2) Tingkat self esteem siswa sebelum diberikan teknik kejutan verbal berada pada kategori rendah kemudian mengalami peningkatan setelah diberikan teknik kejutan verbal yaitu berada pada ketegori sedang, (3) Teknik kejutan verbal berpengaruh signifikan dalam penigkatan self esteem siswa.
\end{abstract}

Kata Kunci: Self Esteem, Teknik Kejutan Verbal

\begin{abstract}
The main problems examined in this research are increasing student self esteem with Verbal Shock Technique. The research aims at discovering (1) the description of the application of verbal shock techniques (2) the level of students 'self esteem before and after implementing verbal shock techniques (3) the effect of verbal shock techniques in increasing students' self esteem. The research approach used is quantitative with preexperimental designs, one group pretest-posttest design. The population and samples of the research were class X students at SMA Negeri 9 Makassar who were identified as having low self esteem with a total sample of 9 students. The instruments used ware scale and observation. The data of the research were analyzed by using descriptive analysis and inferential statistics analysis wth t-test. The results of the research: (1) The implementation of verbal shock techniques through group counseling consisted of five stages namely building a counseling environment, exploring wants and needs, exploring doing and direction, evaluating themselves and plans and actions where students were enthusiastic at each stage carried out. (2) The level of students' self esteem before being given a verbal shock technique is in the low category and then experiencing an increase after being given a verbal shock technique that is in the medium category. (3) Verbal shock techniques have a significant effect on increasing students' self esteem.
\end{abstract}

Keywords: Self Esteem, Verbal Shock Technique

This is an open access article distributed under CC BY-SA 4.0 


\section{PENDAHULUAN}

Menghargai diri sendiri merupakan hal yang sangat penting untuk mencapai perkembangan yang optimal. Penghargaan terhadap diri secara wajar merupakan kunci utama mencapai kesuksesan dalam hidup. Perhargaan terhadap diri diwujudkan oleh siswa melalui perilaku yang tampak dan berdampak pada pencapaian prestasi di sekolah.

Self esteem tinggi ataupun rendah sebenarnya merupakan penilaian yang tumbuh dari individu itu sendiri, yang dalam hal ini adalah bagaimana individu menyikapi dan menilai dirinya sendiri, sehingga jika individu ingin mengubah dirinya untuk mempunyai self esteem yang tinggi, maka individu itu harus belajar untuk menghargai dirinya sendiri.

Kegagalan siswa dalam studi bukan hanya disebabkan oleh rendahnya intelegensi yang dimiliki, kurangnya motivasi, kesalahan memilih sekolah lanjutan tetapi juga disebabkan oleh hal lain, misalnya rendahnya self esteem yang dimiliki siswa. Rendahnya self esteem akan menimbulkan sikap yang dapat menghambat perkembangan individu, sebagaimana yang dinyatakan Alwisol (2004: 256) bahwa Perasaan frustasi karena tidak terpuaskannya kebutuhan harga diri pada individu akan menimbulkan perasaan dan sikap inferior, canggung, lemah, pasif, tergantung, penakut, tidak mampu menghadapi tuntutan hidup dan rendah diri dalam bergaul.

Hal ini juga terjadi di SMA Negeri 9 Makassar, ketika peneliti melakukan wawancara dengan guru pembimbing di sekolah tersebut, diperoleh informasi bahwa terdapat beberapa siswa yang teridentifikasi memiliki self esteem yang rendah. Hal ini ditunjukkan dengan adanya siswa yang tidak berani tampil di depan kelas, tidak mau bergaul dengan teman-temannya, tidak mau mengikuti kegiatan sekolah dengan alasan bahwa siswa tersebut tidak mampu, pasif di dalam kelas, malu mengeluarkan pendapat saat diskusi, suka menyendiri, selalu bersikap canggung, serta takut dikritik. Jika hal tersebut tidak diatasi dengan baik maka dapat menimbulkan dampak negatif misalnya memiliki konsep diri yang negatif atau merasa tidak percaya dengan kemampuan diri sendiri yang akan berdampak pada prestasi belajarnya di sekolah.

Harga diri rendah pada individu/siswa disebabkan oleh keadaan fisik dan psikis serta penerimaan sosial (lingkungan) yang rendah. Individu/siswa yang memiliki harga diri rendah akan mengalami hambatan dalam mencapai perkembangan yang optimal. Mereka akan merasa kurang percaya diri, cenderung menolak dirinya, memiliki kecemasan yang tinggi, kurang mampu bersosialisasi, memilik penyesuaian diri yang rendah, ragu dalam bertindak, cenderung bergantung pada orang lain, tidak kreatif, tidak mampu menerima kritikan, tidak memiliki harapan. Kondisi seperti ini akan menghambat keberhasilan proses belajar di sekolah, olehnya itu sangat dibutuhkan suatu layanan yang dapat membantu mereka untuk meningkatkan harga diri.

Dengan demikian dapat disimpulkan bahwa siswa memiliki self esteem disebabkan karena siswa tersebut memiliki pandangan dan perasaan bahwa dirinya memiliki banyak kekurangan dan lemah dibandingkan orang lain sehingga dari pemikiran (thinking) dan perasaan (feeling) tersebut menyebabkan siswa bertindak (doing and psysiology) secara tidak bertanggung jawab, tidak sesuai realita dan tidak benar. 
Untuk membantu siswa meningkatkan self esteem yang dimiliki, salah satu cara yang dapat dilakukan yaitu dengan memberikan layanan konseling kelompok dengan menerapkan teknik kejutan verbal dari terapi realitas.

Menurut terapi realitas bahwa siswa mengalami self esteem rendah disebabkan karena tidak adanya kesadaran akan tanggung jawab. Olehnya itu, dalam proses konseling, peran guru pembimbing adalah membantu siswa memperoleh kesadaran bahwa perilaku/tindakan yang ditampilkan itu tidak bertanggung jawab. Guru pembimbing dalam menyadarkan perilaku siswa menerapkan suatu keterampilan konseling yakni teknik kejutan verbal yang berupa pemberian kata-kata ejekan/kasar ataupun berupa teguran langsung atas perilaku siswa yang tidak bertanggung jawab, tidak realistis dan tidak benar, atau dengan kata lain guru pembimbing mengonfrontasikan perilaku siswa yang tidak bertanggung jawab. Prinsip kejutan adalah memunculkan situasi distraksi dan kebingungan pada pihak subjek yang menerima kejutan tersebut. Dalam hal ini, guru pembimbing melakukan sesuatu yang tidak lazim atau tak terduga yang menyebabkan distraksi dan kebingungan yang membuat konseli/siswa mengembangkan kekosongan (blank) beberapa saat. Situasi blank inilah yang merupakan momen kreatif dimana guru pembimbing bisa leluasa menyusupkan sugesti, perilaku baru, atau gagasan yang mudah diterima konseli. Proses konseling ini dilakukan dalam 5 tahap yakni: Menbangun relasi, Eksplorasi Keinginan, Kebutuhan dan Persepsi (wants and needs), Eksplorasi Arah dan Tindakan (direction and doing), Evaluasi Diri (self evaluation), Rencana dan Tindakan (planning).

Dengan pemberian teknik kejutan verbal siswa diharapkan dapat merubah secara langsung perilaku dan tindakan (doing) yang tidak bertanggung jawab menjadi perilaku yang bertanggung jawab. Selanjutnya akan mempengaruhi perasaan (feeling) dan pemikiran (thinking) siswa tentang dirinya dan kemampuan yang dimilikinya yang pada akhirnya akan mengubah penilaian terhadap dirinya atau dengan kata lain dapat meningkatkan self esteemnya. Peningkatan self esteem ini ditandai dengan beberapa karakteristik. Menurut Coopersmith, ada beberapa karakteristik individu yang memiliki self esteem positif/tinggi yaitu memiliki tingkat kepercayaan diri yang tinggi, mampu menerima dirinya apa adanya, tidak mencemaskan sesuatu yang belum pasti, mampu bersosialisasi, mampu menyesuaikan diri, memiliki sikap asertif, mandiri, kreatif, memiliki keyakinan akan kemampuannya, mampu menerima kritikan, memiliki harapan dan mendapatkan pengakuan dari orang lain.

Pemberian teknik kejutan verbal ini, diharapkan agar konseli menemukan penyadaran tentang sisi negatif yang ditimbulkan oleh kondisi psikologis dirinya yang memiliki self esteem rendah. Sebagaimana tujuan dari terapi realitas adalah membantu individu untuk mencapai succses identity. Untuk mencapai succes identity diperlukan suatu rasa tanggung jawab dari individu, dan untuk itu individu harus mencapai kepuasan terhadap kebutuhan personal, yaitu kebutuhan akan harga diri/self esteem (Komalasari, 2011).

Menurut Glesser (Winkel \& Hastuti, 2006), perilaku menyimpang merupakan akibat karena tidak adanya kesadaran mengenai tanggung jawab pribadi dalam diri seseorang. Tanggung jawab diartikan sebagai kemampuan untuk dapat memenuhi dua kebutuhan psikologis yang mendasar, yaitu kebutuhan untuk dicintai dan mencintai serta 
kebutuhan menghayati dirinya sebagai orang yang berharga dan berguna atau dengan kata lain memiliki self esteem yang positif.

Dengan demikian siswa diharapkan mampu mencapai success identity yang ditandai dengan adanya kesadaran akan tanggung jawab atau dengan terpenuhinya kebutuhan menghayati diri sebagai orang yang berharga, sehingga siswa dapat meningkatkan penghargaan terhadap dirinya, agar mereka menjadi individu yang memiliki sikap percaya diri, mandiri, aktif, tidak mudah putus asa (optimis), merasa puas dengan keadaan dirinya, merasa sejajar dan bahkan lebih dari orang lain serta dapat mencapai keberhasilan dalam hidup.

\section{METODE}

Pendekatan dalam penelitian ini adalah pendekatan penelitian kuantitatif, Jenis penelitian yang digunakan pre-experimental One Group Pre-test dan Post- test Design. Dalam penelitian ini mengkaji dua variabel yaitu, Teknik Kejutan Verbal (X) dan Harga Diri (self esteem) (Y).

Teknik Kejutan Verbal (X) merupakan salah satu teknik dalam terapi Realitas dengan memberikan kata-kata kasar/mengejek dan berupa teguran langsung kepada siswa untuk mengonfrontasikan tingkah laku yang tidak realistis. Teknik ini dilakukan dalam konseling kelompok yang terdiri atas lima tahap, yaitu: 1) Membangun relasi/ lingkungan konseling; 2) Eksplorasi keinginan, kebutuhan dan persepsi (wants and needs); 3) Eksplorasi arah dan tindakan (direction and doing); 4) Tahap evaluasi diri (self evaluation); 5) Rencana dan Tindakan (planning). Sedangkan harga diri (self esteem) (Y) merupakan penilaian yang dibuat oleh seseorang terhadap kemampuan dirinya dan dinyatakan oleh seseorang dengan bertindak, berkeyakinan serta sejauh mana menilai dirinya secara positif maupun negatif, merasa mampu atau tidak dan berharga atau tidak berharga.

Penelitian ini dilaksanakan di SMA Negeri 9 Makassar. dengan jumlah populasi 72 siswa yang teridentifikasi memiliki self esteem rendah dengan menarik sampel penelitian secara simple random sampling sebanyak 9 orang.

Teknik pengumpulan data yang digunakan dalam penelitian ini adalah skala dan observasi. Data-data yang diperoleh melalui skala self esteem siswa yang dibuat sendiri oleh peneliti dimana sebelum dipakai dalam penelitian diuji validitas terlebiih dahulu oleh ahli yang berkompeten dalam bimbingan dan konseling selanjutnya diuji lapangan terbatas untuk mengetahui validitas dan realibilitasnya. Teknik analisis data yang digunakan untuk mengolah data adalah analisis statistik deskriptif, analisis statistik inferensial serta $t$-test menggunakan SPSS 16.

\section{HASIL TEMUAN}

Berdasarkan hasil penelitian yang dilaksanakan di SMA Negeri 9 Makassar terhadap 9 orang siswa guna mengetahui self esteem siswa sebelum dan sesudah diberikan teknik kejutan verbal. 
Pelaksanaan teknik kejutan verbal yang diberikan berlangsung selama 6 kali pertemuan. Adapun analisis statistic deskriptif gambaran tingkat self-esteem siswa dari hasil pretest dan posttest sebagai berikut.

Tabel 1. Data Tingkat Self Esteem Siswa Sebelum dan Sesudah diberikan Konseling kelompok dengan teknik kejutan verbal di SMA Negeri 9 Makassar

\begin{tabular}{|c|c|c|c|c|c|}
\hline \multirow{3}{*}{ Interval } & \multirow{3}{*}{ Kategori } & \multicolumn{4}{|c|}{ Sampel penelitian } \\
\hline & & \multicolumn{2}{|c|}{ Pretest } & \multicolumn{2}{|c|}{ Postest } \\
\hline & & Frekuensi & Persentase & Frekuensi & Persentase \\
\hline $147-172$ & Sangat tinggi & 0 & 0 & 0 & 0 \\
\hline $121-146$ & Tinggi & 0 & 0 & 2 & $22,22 \%$ \\
\hline $95-120$ & Sedang & 4 & $44,44 \%$ & 7 & $77,78 \%$ \\
\hline $69-94$ & Rendah & 5 & $55,56 \%$ & 0 & 0 \\
\hline $43-68$ & Sangat rendah & 0 & 0 & 0 & 0 \\
\hline & Jumlah & 9 & $100 \%$ & 9 & $100 \%$ \\
\hline
\end{tabular}

Tingkat self-esteem siswa SMA Negeri 9 Makassar sebelum diberikan teknik kejutan verbal, berada dalam kategori sedang sebanyak 4 responden $(44,44 \%)$, dan rendah sebanyak 5 responden $(55,56 \%)$. Sedangkan tidak ada responden yang berada kategori sangat rendah, tinggi dan sangat tinggi. Selanjutnya sesuai dengan nilai rata-rata skor yang diperoleh pada nilai pretest sebesar 94 atau berada pada interval 69-94 yang berada pada ketegori rendah. Sehingga dapat disimpulkan bahwa tingkat Self-Esteem siswa di SMA Negeri 9 Makassar berada dalam kategori rendah.

Setelah diberi perlakuan berupa teknik kejutan verbal selama 6 pertemuan, tingkat self-esteem siswa mengalami peningkatan. Hal ini dapat dilihat dari tingkat self-esteem siswa yang berada dalam kategori sedang sebanyak 7 responden $(77,78 \%)$ dan kategori tinggi sebanyak 2 reponden $(22,22 \%)$, dan tidak ada responden yang berada pada kategori sangat rendah, rendah dan sangat tinggi. Selanjutnya sesuai dengan nilai rata-rata skor yang diperoleh sebesar 108,89 yang berada pada interval 95-120 menunjukkan sedang. Hal ini menunjukkan bahwa tingkat self-esteem siswa di SMA Negeri 9 Makassar setelah diberikan teknik kejutan verbal berada pada kategori sedang.

Selama pemberian teknik kejutan verbal peneliti juga melakukan observasi. Hasil observasi tersebut dapat dilihat pada tabel berikut:

Tabel 2. Data Hasil Persentasi Observasi Penerapan Teknik Kejutan Verbal

\begin{tabular}{cccccccc}
\hline \multirow{2}{*}{ Persentase } & \multirow{2}{*}{ Kriteria } & \multicolumn{7}{c}{ Pelaksanaan kegiatan pertemuan ke } \\
\cline { 2 - 8 } & & $\mathbf{1}$ & $\mathbf{2}$ & $\mathbf{3}$ & $\mathbf{4}$ & $\mathbf{5}$ & $\mathbf{6}$ \\
\hline $80-100 \%$ & Sangat Tinggi & & & & & & 2 \\
\hline $60--79 \%$ & Tinggi & & 3 & 5 & 1 & 2 & 4 \\
\hline $40-59 \%$ & Sedang & 5 & 6 & 4 & 8 & 7 & 3 \\
\hline $20-39 \%$ & Rendah & 4 & & & & & \\
\hline $0-19 \%$ & Sangat rendah & & & & & & \\
\hline Jumlah & & 9 & 9 & 9 & 9 & 9 & 9 \\
\hline
\end{tabular}


Pelaksanaan observasi ini dilakukan untuk melihat bagaimana gambaran partisipasi siswa mengikuti kegiatan konseling kelompok dengan teknik kejutan verbal. Berdasarkan hasil pengamatan pada pertemuan pertama, terdapat 4 orang siswa yang berada pada kategori sangat rendah, 5 orang siswa yang berada pada kategori sedang. Pada pertemuan kedua, terdapat 6 orang siswa yang berada pada kategori sedang dan 3 orang siswa berada pada kategori tinggi. Ini menunjukkan adanya peningkatan partisipasi siswa mengikuti kegiatan konseling kelompok jika dibandingkan pada pertemuan pertama. Pada pertemuan ketiga, terdapat 4 orang siswa berada pada kategori sedang, dan 5 orang siswa pada kategori tinggi. Pada pertemuan keempat terdapat 8 orang siswa berada pada kategori sedang, 1 orang siswa berada pada kategori tinggi. Hal ini menunjukkan bahwa partisipasi siswa pada pertemuan keempat mengalami penurunan yang diakibatkan oleh kejenuhan. Selanjutnya pada pertemuan kelima terdapat 7 siswa yang berada pada kategori sedang, dan 2 siswa berada pada kategori tinggi. Pada pertemuan keenam, terdapat 3 siswa berada pada kategori sedang, 4 orang pada kategori tinggi dan 2 orang berada pada kategori sangat tinggi. Hal ini menunjuukkan adanya peningkatan partisipasi siswa dalam mengikuti kegiatan konseling kelompok meskipun sempat mengalami kejenuhan. Berdasarkan hasil yang diperoleh maka setiap pertemuan partisipasi siswa mengalami peningkatan dan memberikan bukti bahwa kegiatan yang dilaksanakan dapat diikuti dengan baik oleh para siswa.

Berdasarkan hasil penghitungan dengan menggunakan SPSS 16.00 for windows melalui Wilcoxon signed ranks test terdapat perbedaan nilai rata-rata setelah perlakuan lebih tinggi daripada sebelum diberikan perlakuan yakni sebelum diberi perlakuan nilai rata-ratanya sebesar 94 namun setelah diberi perlakuan terjadi perubahan menjadi 108,89. Taraf signifikansi yang digunakan $5 \%$ atau 0,05 , dengan kriteria adalah tolak Ho jika nilai Asymp. Sig $<\alpha$ dan diterima $\mathrm{H}_{0}$ jika nilai Asymp. Sig $>\alpha$. Berdasarkan uji statistik diperoleh nilai Asymp. Sig (2-tailed) yaitu $0,007<\alpha$. Hal ini berarti bahwa hipotesis nol $\left(\mathrm{H}_{\mathrm{o}}\right)$ yang yang menyatakan bahwa "Tidak Ada Pengaruh Penerapan Teknik Kejutan Verbal Dalam Meningkatkan Self Esteem Siswa di SMA Negeri 9 Makassar" dinyatakan ditolak. Sehingga hipotesis alternative $\left(\mathrm{H}_{1}\right)$ yang menyatakan bahwa "Ada Pengaruh Penerapan Teknik Kejutan Verbal Dalam Meningkatkan Self Esteem Siswa di SMA Negeri 9 Makassar" dinyatakan diterima dengan adanya perubahan yang signifikan. Dengan demikian dapat disimpulkan bahwa penerapan teknik kejutan verbal dapat meningkatkan self esteem siswa di SMA Negeri 9 Makasssar.

\section{PEMBAHASAN}

Harga Diri (self esteem) merupakan penilaian yang dibuat oleh seseorang terhadap kemampuan dirinya dan dinyatakan oleh seseorang dengan bertindak, berkeyakinan serta sejauh mana menilai dirinya secara positif maupun negatif, merasa mampu atau tidak dan berharga atau tidak berharga. Meningkatnya harga diri pada individu ditandai dengan adanya karakteristik yaitu memiliki rasa percaya diri yang tinggi, penerimaan diri, kecemasan rendah, mampu bersosialisasi, mampu menyesuaikan diri, memiliki sikap asertif, mandiri, memiliki kreatifitas, memiliki keyakinan akan kemampuannya, mampu menerima kritikan, memiliki harapan, mendapatkan pengakuan dari orang lain (Santrock, 
2008).

Penjelasan diatas sejalan dengan pandangan Terapi Realita terhadap perilaku manusia yang merupakan perilaku total, dimana perasaan (feeling), pikiran (thinking), tindakan (doing) dan respon fisiologis (physiology) saling mempengaruhi. Untuk membantu siswa meningkatkan harga dirinya maka siswa harus membiasakan diri untuk berperilaku bertanggungjawab sehingga mempengaruhi perasaan dan pemikirannya. Salah satu cara yang bisa dilakukan yaitu dengan menerapkan teknik kejutan verbal terhadap siswa yang memiliki harga diri rendah. (Palmer, 2011); (Corey, 2009).

Penerapan teknik kejutan verbal ini merupakan salah satu teknik dari terapi realitas dengan memberikan kata-kata ejekan ataupun teguran langsung untuk mengonfrontasikan perilaku siswa yang tidak bertanggung jawab atau yang mencerminkan harga diri rendah. Prinsip kejutan adalah memunculkan situasi distraksi dan kebingungan pada subjek yang menerima kejutan tersebut. Dalam hal ini, peneliti ataupun guru pembimbing melakukan sesuatu yang tak terduga yang menyebabkan distraksi yang membuat konseli/siswa mengembangkan kekosongan. Pada situasi blank inilah yang disebut momen kreatif dimana konselor bisa leluasa menyusupkan sugesti, perilaku baru, atau gagasan yang mudah diterima konseli.

Sejalan dengan hal tersebut, secara umum siswa SMA Negeri 9 Makassar yang menjadi sampel penilitian memiliki tingkat harga diri (self esteem) yang rendah

Pemberian konseling kelompok dengan teknik kejutan verbal merupakan salah satu cara untuk membantu siswa meningkatkan harga dirinya. Dimana siswa diarahkan untuk menampilkan perilaku yang bertannggun jawab yang akan mempengaruhi penilaian terhadap dirinya dan mampu meningkatkan harga dirinya.

Pelaksanaan konseling kelompok dengan menerapkan teknik kejutan verbal ini terbagi atas 5 tahapan. Tahap pertama yaitu membangun lingkungan konseling dimana peniliti berusaha menjalin hubungan baik dengan konseli, membangun suasana hangat dan bersahabat serta mengarahkan konseli agar mau berkomitmen melaksanakan konseling kelompok.

Tahap kedua adalah eksplorasi keinginan, kebutuhan dan persepsi konseli terhadap berbagai aspek kehidupannya, dalam tahap ini peneliti berusaha mengarahkan konseli pada eksplorasi yang berkaitan dengan harga diri.

Tahap ketiga yaitu eksplorasi arah dan tindakan, pada tahap ini peneliti menggunakan permainan sebagai salah satu alat untuk memancing konseli memunculkan perilaku yang tidak bertanggung jawab, Inti dari kegiatan ini adalah melatih konseli untuk berperilaku yang bertanggungjawab sehingga dengan pembiasaan tersebut konseli mampu mengetahui dan mengakui kemampuannya yang pada akhirnya akan mempengaruhi penilaian terhadap dirinya, dan akan meningkatkan penghargaan terhadap dirinya.

Tahap keempat adalah evaluasi diri, pada tahap ini peneliti mengarahkan siswa untuk mengevaluasi kegiatan yang telah dilakukan dan mengevaluasi apakah teknik yang diberikan bermanfaat untuk mereka.

Tahap terakhir yaitu rencana dan tindakan, pada tahap ini peneliti mengarahkan siswa untuk merumuskan suatu rencana tindakan realistis yang dapat membantu meningkatkan harga diri mereka. Dan kemudian mengarahkan siswa untuk berkomitmen 
merealisasikan hal-hal yang telah direncanakan.

Berdasarkan hasil observasi yang dilakukan selama proses konseling kelompok dilakukan, partisipasi konseli pada pertemuan pertama masih rendah, pertemuan kedua dan ketiga mulai meningkat, namun agak menurun pada pertemuan keempat, selanjutnya pada pertemuan kelima dan keenam perhatian dan partisipasi siswa mengikuti kegiatan meningkat lagi. Hal ini menunjukkan bahwa siswa memiliki keseriusan dan antusias yang tinggi mengikuti setiap kegiatan yang merupakan salah satu gambaran tentang adanya peningkatan harga diri pada siswa yang mengikuti konseling kelompok.

\section{SIMPULAN}

Berdasarkan hasil penelitian mengenai penerapan teknik kejutan verbal untuk menigkatkan self-esteem siswa SMP Negeri 9 Makassar, maka disimpulkan bahwa: 1) Pelaksanaan teknik kejutan verbal dilakukan melalui konseling kelompok yang terdiri atas 5 tahap, yaitu membangun lingkungan konseling, eksplorasi Wants and Needs, eksplorasi doing and direction, evaluasi diri serta rencana dan tindakan. Pelaksanaan konseling kelompok dengan teknik kejutan verbal ini diikuti dengan penuh antusias oleh siswa, terlihat dari adanya peningkatan partisipasi pada setiap tahap yang dilaksanakan. 2) Tingkat self-esteem siswa di SMA Negeri 9 Makassar sebelum diterapkan teknik kejtan verbal berada pada kategori rendah, akan tetapi setelah diberikan teknik kejutan verbal dalam bentuk konseling kelompok, tingkat self esteem siswa mengalami peningkatan yaitu berada pada kategori tinggi. 3) Penerapan teknik kejutan verbal berpengaruh signifikan terhadap peningkatan self esteem siswa di SMA Negeri 9 Makassar. Artinya bahwa pemberian teknik kejutan verbal ini dapat membantu meningkatkan self esteem siswa di SMA Negeri 9 Makassar.

Berdasarkan kesimpulan hasil penelitian diatas, maka adapun saran pada penelitian ini adalah: 1) Guru pembimbing, hendaknya dapat menerapkan teknik kejutan verbal sebagai salah satu solusi dalam meningkatkan self-esteem siswa. 2) Siswa, hendaknya senantiasa mampu menyadari secara mandiri perilakunya yang tidak bertanggunga jawab sehingga mampu mengubahnya dan menampilakan sikap dan perilaku yang realistis sehingga memiliki self esteem posistif/tinggi. 3) Kepada rekan-rekan mahasiswa dan peneliti di Jurusan bimbingan dan konseling, agar dapat mengembangkan teknik kejutan verbal ini pada permasalahan yang berbeda agar dapat dijadikan sebagai bahan perbandingan.

\section{DAFTAR PUSTAKA}

Corey, Gerald. (2009). Teori dan Praktek Konseling dan Psikoterapi. Diterjemahkan oleh Koeswara. Bandung: Refika Aditama.

Halimah, Lilin \& Elcamila, Faya Noorhalia. (2010). Self Esteem dan Relasi Interpersonal Penyandang Tunarungu di Lembaga Deaf ' $n$ Dum. Humanitas Indonesian Psychological Journal Vol.7 No.2, (Online).

Komalasari, Gantina, Wahyuni, Eka \& Karsih. (2011). Teori dan Teknik Konseling. Jakarta: Indeks. 
Penerapan Teknik Kejutan Verbal untuk Meningkatkan Self Esteem Siswa

- Idriani Idris, Arni Ulan

Palmer, Stephen. 2011. Konseling dan Psikoterapi. Diterjemahkan oleh Haris Setiadjid. Yogyakarta: Pustaka Pelajar.

Santrock, Jhon W. (2002). Life Span Development I Perkembangan Masa Hidup. Diterjemahkan oleh Achmad Chusairi dan Juda Damanik. Jakarta: Erlangga.

Sugiyono. (2011). Metode Penelitian Pendidikan Pendekatan Kuantitatif, Kualitatif, dan $R$ \& D. Bandung: Alfabeta.

Sulistyowati, Wida dan Warsito, Hadi. (2009). Artikel: Penerapan Konseling Realita untuk Meningkatkan Harga Diri Siswa, Jurnal BK UNESA Vol 1 No.1. (Online). 